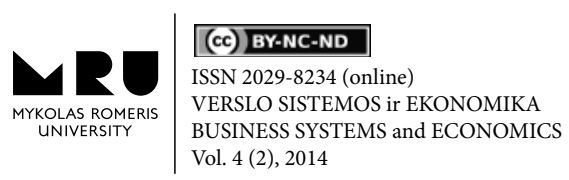

\title{
NEMATERIALAUS TURTO SAMPRATA: IŠTAKOS, APIBRĖŽIMAI, SAVYBĖS IR ELEMENTAI
}

\author{
Raimundas DUŽINSKAS \\ Mykolo Romerio universitetas \\ Ateities g. 20, LT-08303 Vilnius, Lietuva \\ El. paštas: rduzinskas@gmail.com

\section{Artūras JURGELEVIČIUS} \\ Mykolo Romerio universitetas \\ Ateities g. 20, LT-08303 Vilnius, Lietuva \\ El. paštas: jurgeleviciusarturas@yahoo.co.uk
}

doi:10.13165/VSE-14-4-2-08

\begin{abstract}
Santrauka. Nematerialaus turto konceptualiosios žinios dar nesuformavo savo sanklodos ekonomikos moksle. Nematerialaus turto tyrimų sričiai impulsą suteikè tyrimai apskaitos teorijos ir praktikos srityje. Tačiau dèl savo materialaus pavidalo nebuvimo, sunkumų identifikuojant, išmatuojant ir vertinant, nematerialaus turto tyrimų sritis ekonomistų ilgą laiką buvo ignoruojama. XX a. antroje pusejje padidejęs įmonių produktyvumas buvo aiškinamas kokybiškesniais žmogiškaisiais ištekliais ir technologine pažanga. Tik XX a. pab. atlikti pirmieji tyrimai siūlo daryti išvadą, kad nematerialios ekonomikos augimas didele dalimi gali būti paaiškintas nematerialaus turto naudojimu gamybos ar paslaugu teikimo procese, efektyvinant juos. Straipsnyje apžvelgiamos nematerialaus turto ištakos, pateikiama nematerialaus turto ekonominès minties istorijos raida, lemianti nematerialaus turto formavimąsi, gvildenami nematerialaus turto probleminiai klausimai, apibrěžiami pagrindiniai nematerialụji turtą sudarantys elementai.
\end{abstract}

Reikšminiai žodžiai: nematerialus turtas, nematerialaus turto ekonominès minties istorijos raida, nematerialaus turto samprata, nematerialaus turto elementai.

JEL klasifikacija: C21, D24.

\section{Ivadas}

Klasikinès ekonomikos teorijos tik iš dalies gali paaiškinti šiuolaikinius ekonomikos vyksmus. Ekonomikos augimo teorijos buvo puoselejjamos ir aiškinamos tokių klasikų kaip Marxas, Smith's, Riccardo, Schumpeteris, Beckeris ir kitų. Tradiciniai gamybos veiksniai sulaukè daug ekonomistų dėmesio. Tačiau šiuolaikinèje ekonomikoje vykstantys sudètingi procesai reikalauja naujų metodų ir metodologijos, siekiant paaiškinti tuos pačius procesus: produktyvumą, efektyvumą, konkurencingumą ir ekonomikos augimą. Sunkiai paaiškina- 
mas produktyvumo padidejimas $\mathrm{XX}$ a. antroje pusèje laikytinas nematerialaus turto tyrimų srities pradžia. Vis dèlto ženkliai padidèjęs produktyvumas tuo metu buvo aiškinamas kokybiškesniais žmogiškaisiais ištekliais ir technologine pažanga, konkrečiai dar nesiejant to su nematerialiuoju turtu.

Nematerialus turtas ilgą laiką buvo ekonomistų ignoruojamas dèl savo materialaus pavidalo savybių nebuvimo. Nagrinèdami nematerialųjį turtą, mokslininkai susiduria su nematerialaus turto identifikavimo, išmatavimo ir vertinimo problemomis. Moksliniuose tyrimuose vyraujanti sritis yra nematerialaus turto išmatavimo ir poveikio produktyvumui vertinimas. Atlikti reikšmingi darbai nustato teigiamą ryši produktyvumo padidejjimui (Dal Borgo et al., 2012; Corrado et al., 2012). Atlikti makro- ir mezolygmens tyrimai rodo, kad investicijos ị nematerialujji turtą paaiškina iki 50 \% darbo jẻgos produktyvumo (Roth ir Thum, 2013; Melachrionos ir Spence, 2012). Nematerialus turtas daro teigiamą poveiki darbo jègos produktyvumui ir bendram produktyvumo lygiui (Marrocu et al., 2012; Riley et al., 2011). Jeigu išlaidos ị nematerialụji turtą būtų tinkamai apskaitytos ịmonių ir nacionalinèse sąskaitose, Europos Sąjungos šalyse BVP augimo tempai vidutiniškai padidètų $5 \%$ (Piekkola, 2011). Nepaisant minètų tyrimų, mažai mokslinių darbų analizuoja nematerialaus turto sampratą ir jos elementus. Tyrimuose autoriai naudoja skirtingus nematerialaus turto elementus, todèl tampa sunku investicijų i nematerialųji turtą dydžius lyginti tarp šalių, ūkio šakų ar atskirų ūkio subjektų bei keblu formuoti bendrą nematerialaus turto tyrimų metodologiją.

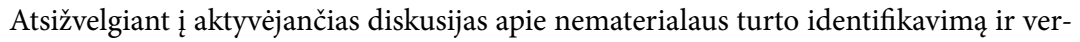
tinimą, aktualu atskleisti nematerialaus turto prigimtį ir sampratą ekonominès minties istorijos raidos kontekste.

Tyrimo objektas - nematerialus turtas.

Tyrimo tikslas - išanalizavus nematerialaus turto formavimuisi įtakos turèjusią ekonominès minties istorinę raidą bei nematerialaus turto identifikavimo probleminius klausimus, ịvardinti pagrindinius nematerialaus turto elementus ir pateikti universalų nematerialaus turto apibrěžimą.

Tyrimo metodai - sisteminè mokslinès literatūros analizè, apibendrinimas.

\section{Nematerialaus turto ekonominès minties istorijos raida}

Nematerialaus turto samprata nèra galutinai atskleista mokslinèje literatūroje. Todèl nematerialaus turto konceptualiosios žinios pastaruoju metu tapo mokslininkų diskusijų objektu. Pastruosius dešimtmečius mokslininkai plètojo fizinio, finansinio, o vèliau ir žmogiškojo kapitalo ekonominę mintị. Keičiantis gamybos veiksniams, sparčiai vystantis globalizacijai bei žmonijos technologiniam proveržiui, tradicinius kapitalo šaltinius pakeitè nauji - nematerialūs ištekliai. Nematerialūs ištekliai suprantami kaip žiniomis grindžiamos ekonomikos varomoji jèga. Bendrąja prasme, nematerialūs ištekliai neturi materialios formos ar kitokių apčiuopiamumo savybių. Nors nematerialių išteklių konceptualiosios žinios dar nesuformavimo savo sanklodos ekonomikos moksle, nematerialių išteklių prigimtis siejama su žmogaus ekonomine, socialine, intelektine veikla. Daugkartiniai ekonomikos augimo tyrimai lèmé nematerialaus turto sampratos formavimąsi (1 lent.). 
1 lentelè. Nematerialaus turto sampratos formavimąsi lėmusios ekonominès koncepcijos

\begin{tabular}{|c|c|c|}
\hline $\begin{array}{l}\text { Ekonominès } \\
\text { koncepcijos }\end{array}$ & Pagrindinès mintys & Autoriai \\
\hline $\begin{array}{l}\text { Kapitalo kaupimo ir } \\
\text { ekonomikos augimo } \\
\text { teorija }\end{array}$ & $\begin{array}{l}\text { Ekonomikos augimas matomas kaip materialaus } \\
\text { kapitalo kaupimas ir darbo jègos produktyvumas }\end{array}$ & Smith (1776) \\
\hline Darbo vertės teorija & $\begin{array}{l}\text { Galutinio produkto vertę kuria ne kapitalas, bet } \\
\text { darbo jėga ir darbo jègos kiekis }\end{array}$ & Marx (1867) \\
\hline $\begin{array}{l}\text { Konstruktyviosios } \\
\text { destrukcijos teorija }\end{array}$ & $\begin{array}{l}\text { Kapitalizmas yra ekonomikos kaitos metodas. } \\
\text { Kapitalizmo varomoji jèga yra naujų produktų } \\
\text { kūrimas, naujų klientų pritraukimas, naujų } \\
\text { gamybos metodų kūrimas ir t. t. Visa tai turi } \\
\text { būti paremta mokslo pažanga. Šiuos procesus } \\
\text { Schumpeteris įvardijo kaip inovacijas. }\end{array}$ & Schumpeter (1942) \\
\hline $\begin{array}{l}\text { Endogeninio } \\
\text { ekonomikos augimo } \\
\text { teorija }\end{array}$ & $\begin{array}{l}\text { Be technologinės pažangos, paremtos žiniomis, } \\
\text { ekonomikos augimas neịmanomas }\end{array}$ & $\begin{array}{l}\text { Solow (1956), } \\
\text { Swan (1956) }\end{array}$ \\
\hline $\begin{array}{l}\text { Žmogiškojo kapitalo } \\
\text { teorija }\end{array}$ & $\begin{array}{l}\text { Ekonomikos augimas ir produktyvumas } \\
\text { priklauso nuo žmogiškojo kapitalo. Žmogiškasis } \\
\text { kapitalas užtikrina darnụji ekonomikos augimą, } \\
\text { o išsilavinimas ir sveikata yra fundamentalios } \\
\text { žmogiškojo kapitalo komponentès }\end{array}$ & $\begin{array}{l}\text { Mincer 1958), } \\
\text { Goodé (1959), } \\
\text { Becker (1962), } \\
\text { OECD (2001) }\end{array}$ \\
\hline $\begin{array}{l}\text { Tvaraus ekonomikos } \\
\text { augimo teorija }\end{array}$ & $\begin{array}{l}\text { Bendro kapitalo lygis turi dideti laike. Vèliau teorija } \\
\text { išplèsta - dabartinès kartos vartojimas ir išteklių } \\
\text { naudojimas neturi riboti ateities kartos poreikių } \\
\text { tenkinimo }\end{array}$ & \begin{tabular}{|l|} 
Repetto (1986), \\
Pezzy (1992), \\
Solow (1974), \\
Hartwick (1977) \\
\end{tabular} \\
\hline $\begin{array}{l}\text { Žiniomis grindžiamos } \\
\text { ekonomikos teorija }\end{array}$ & $\begin{array}{l}\text { Ekonomikos augimas paremtas technologijomis, } \\
\text { mokslo pažanga ir žiniomis. Žinios didina } \\
\text { produktyvumą, kuria naujus produktus ir aukštą } \\
\text { vertę }\end{array}$ & $\begin{array}{l}\text { Klein ir Rosenberg } \\
(1986) \\
\text { OECD }(1996)\end{array}$ \\
\hline $\begin{array}{l}\text { Naujojo augimo } \\
\text { teorija }\end{array}$ & $\begin{array}{l}\text { Kapitalo kaupimas yra ribotas ir baigtinis procesas, } \\
\text { todèl tik naujos žinios ir technologijos gali didinti } \\
\text { ekonomikos augimą ir visuomenès pažangą }\end{array}$ & Romer (1994) \\
\hline $\begin{array}{l}\text { Intelektinio kapitalo } \\
\text { teorija }\end{array}$ & $\begin{array}{l}\text { Intelektinis kapitalas generuoja žinias ir kuria } \\
\text { aukštą vertę ateityje. Intelektinis kapitalas didina } \\
\text { produktyvumą ir ekonomikai suteikei visiškai } \\
\text { naujas charakteristikas }\end{array}$ & $\begin{array}{l}\text { Edvinsson ir } \\
\text { Malone (1997), } \\
\text { Stewart (1997), } \\
\text { Edvinsson ir } \\
\text { Sullivan (1998). } \\
\end{array}$ \\
\hline $\begin{array}{l}\text { Nematerialaus turto } \\
\text { teorija }\end{array}$ & $\begin{array}{l}\text { Nematerialus turtas yra nematerialūs ištekliai. } \\
\text { Nematerialaus turto šaltiniai yra mokslo pažanga, } \\
\text { žmogaus energija ir intelektinis potencialas. } \\
\text { Nematerialus turtas kuria vertę ateityje }\end{array}$ & $\begin{array}{l}\text { Kendrick (1961), } \\
\text { Corrado et al. (2006, } \\
\text { 2005) }\end{array}$ \\
\hline
\end{tabular}

Šaltinis: sudaryta autorių

Iš 1 lentelëje pateikto ekonominių koncepcijų raidos klasifikavimo matyti, kad nematerialaus turto konceptualiosios žinios netiesiogiai, bet nuosekliai formavosi kaip ekonominès minties rezultatas. Darbo jègos ir mokslo pažangos aktualumas buvo svarbus jau Marxo laikais. Ekonomikos klasikai iž̌velgè, kad materialaus kapitalo kaupimas negali užtikrinti nuolatinių ekonomikos augimo tempų, o dèl augančios konkurencijos mažeja grąža, gaunama iš 
kapitalo. Klasikiniuose ekonomikos augimo modeliuose nematerialūs produktyvumą lemiantys veiksniai buvo apibrěžiami kaip technologine pažanga, žinios, žmogiškasis kapitalas, nors atskiram nematerialaus turto koncepcijos formavimui daugiau demesio nebuvo skiriama.

Labai svarbų vaidmenį nematerialaus turto sampratos formavimuisi ir šios tyrimų srities išryškejjimui ịtakos turẻjo įmonių taikomi turto apskaitos principai. Turto apskaitos principai buvo pradèti tyrinèti dar $1962 \mathrm{~m}$. Amerikiečių mokslininkas Denisonas (1963, 1967, 1979), tyrinédamas JAV ekonomikos augimo šaltinius, prièjo prie išvados, kad žinios, igūdžiai ir darbo jègos energija yra svarbūs ekonomikos augimo komponentai. Tuo metu buvo tyrinëjama ir skirtingų veiksniu itaka ekonomikos augimui (Kendrick, 1961; Jorgenson, 1963; Griliches, 1984). Mokslininkai darbo jègos ir kapitalo produktyvumo svarbą ekonomikos plètrai ịvardijo abstrakčiau - kaip „daugiakriterini produktyvumą“. Abstraktesnis autorių suvokimas rodo, kad mokslininkai savo tyrimuose suprato, kad faktorių, lemiančiu ekonomikos augimą, aibè yra daug platesnè. Savo tyrimuose autoriai pastebejo ženklų produktyvumo lygio padidejimą. Skirtumas tarp įeigos ir išeigos buvo neadekvatus. Toks neapaiškinamas skirtumas mokslinèje literatūroje buvo vadinamas „likutiniu produktyvumu“. Autoriai prièjo prie išvados, kad produktyvumas padidejo dèl efektyvesnès ir kokybiškos darbo jègos. Jorgensonas (1963) teigè, kad nepaaiškinamas produktyvumo padidèjimas būtų labiau suprantamas, jeigu darbo jèga, kaip įeigos veiksnys, būtų tinkamai apibrežta, įtraukiant išsilavinimo, igūdžių ir žinių paaiškinimus. Tačiau Abramovitzius ir Davidas (1996) našumo padidèjimą darbo jègos vienetui aiškino kaip kapitalo padidèjimą vienam darbo jègos vienetui. Kiti mokslininkai teigè, kad neadekvačiai padidèjęs produktyvumas gali būti paaiškinamas investicijomis ị žmogiškajji kapitalą (Griliches, 1967).

Vienas pirmųjų mokslinę nežinomybę pabandè įveikti Kendricas (1994). Autorius pasiūle ženkliai išplèsti klasikinio kapitalo formavimo supratimą, ị kapitalo formavimo procesą įtraukiant išlaidas išsilavinimui, kvalifikacijos kèlimui, MTTP, programinei ịrangai ir kai kurias išlaidas, susijusiąs su reorganizavimo procesais ir rinkodara, kaip efektyvumą didinančias investicijas (Kendrick, 1994). Investicijos buvo traktuojamos kaip dabartinių išteklių panaudojimas naudai gauti ir vertei padidinti ateityje. Tai vienas pirmųjų mokslininkų, apskaičiavusių nematerialias investicijas, jų proporcijas su materialiosiomis investicijomis ir santyki su BVP Jungtinèse Amerikos Valstijose XX a. Tyrimai atskleidé, kad bendras kapitalo formavimo lygis nepakito, tačiau ženkliai pasikeitè santykis tarp investicijų i materialụji ir nematerialujji turtą. Kadangi nematerialaus kapitalo formavimas dèl savo sudetingų identifikavimo, apibrěžtumo, vertinimo ir išmatavimo savybių nebuvo laikomas kapitalo formavimu, ekonomikos, apskaitos mokslininkai ir praktikai neskyrè daugiau demesio nematerialaus turto koncepcijai formuoti ir nagrinetti.

Kitą svarų indèli nematerialaus turto tyrimuose įnešè amerikiečių mokslininkai (Corrado, Hulten ir Sichel, 2006, 2005). Autoriai daug demesio skyrè kapitalo sampratos performavimui. Kapitalo formavimo principai yra labai svarbūs, kadangi tai nulemia kapitalo skaičiavimo metodologiją ir galutines kapitalo kiekybines išraiškas. Autoriai teigia, kad bet koks išteklių naudojimas, kuris sumažina dabarties vartojimą tam, kad vartojimą padidintų ateityje, turi būti apibrěžiamas kaip investicijos. Anot mokslininkų, investicijos ị žinių kapitalą turètų būti klasifikuojamos taip pat kaip investicijos ị ịrenginius ir mašinas. Mokslininkai (Corrado et al., 2006) išplète inovacinès nuosavybès kategorijas, kurios paprastai nebuvo vadinamos nematerialiuoju turtu. Amerikiečių mokslininkų grupe (2006) apibendrino, suformavo, o veliau ir pritaikè nematerialaus turto modeli OECD šalyse. Vèliau, 2011, modelis buvo pritaikytas ir Europos Sąjungos šalyse. Amerikiečių mokslininkų 
tyrimus pratęsè D. Britanijos mokslininkai Marrano ir Haskelas (2006). Autoriai patvirtino Corrado et al. (2006) tyrimus, nors investicijų i nematerialųji kapitalą svarba D. Britanijoje neženkliai skyrèsi nuo JAV.

\section{Nematerialus turtas: apibrēžimai, savybės ir elementai}

Nematerialios ekonomikos sąlygomis keičiasi ne tik gamybos ar paslaugų teikimo procesas, bet ir sukurtos ekonominės vertès suvokimas. Vis dažniau gamybos procese naudojamas nematerialus turtas sukuria didejjančią pridètinę vertę i̇monei negu materialus kapitalas. Gamyba ir prekyba paremti ekonominiai santykiai yra pakeičiami žiniomis, informacija, žmogaus intelektiniais sugebejjimais - labai svarbiais, bet neapčiuopiamais ir plika akimi nematomais elementais. Dèl šios priežasties ilgą laiką visų šalių mokslininkai ignoravo nematerialaus turto tyrimų sriti.

Užsienio literatūroje vartojami keletas plačiai paplitusių terminų: nematerialus turtas (angl. intangible assets), nematerialus kapitalas (angl. intangible capital), nematerialūs ištekliai (angl. intangible resources), intelektinis kapitalas (angl. intellectual capital). Daugelis autorių sutinka, kad egzistuoja neženklūs skirtumai tarp šių koncepcijų, bet esminių skirtumų neišskiria ir šiuos terminus vartoja kaip sinonimus arba vienas kitą papildančias sąvokas (Teece, 2009; Gu ir Lev, 2002; Granstrand, 1999). Mackevičius ir Jarmalaitė (2011) daro išvadas, kad nematerialaus turto, nematerialių išteklių ir intelektinio kapitalo terminai dažnai tapatinami, ir siūlo šiuos terminus atskirti.

Nematerialus turtas savo prigimtimi sunkiai identifikuojamas, apibrěžiamas ir išmatuojamas. Visiško mokslininkų sutarimo, kaip apibrěžti nematerialųji turtą, nèra. Tačiau iš mokslinèje literatūroje pateikiamų apibrèžimų (2 lent.) galima būtų identifikuoti kelias bendrąsias nematerialaus turto savybes (1 schema.).

Apibendrinant mokslininkų įvairias nematerialaus turto traktuotes galima teigti, kad nematerialus turtas neturi fizinio pavidalo, jo negalima plika akimi ižvelgti ar apčiuopti. Nematerialus turtas yra visiškai kitokia materija, priešinga klasikiniam turto ar kapitalo suvokimui. Taip pat skirtingų mokslinių įžvalgų autoriai sutinka, kad nematerialus turtas neturi finansinès dimensijos ir yra atskira turto rūšis. Taip pat sutariama, kad didelè nematerialaus turto dalis tiesiogiai neatsispindi įmonių finansinių rinkinių ataskaitose, tačiau neapskaitomas nematerialus turtas verslui kuria pridètinę vertę. Būtina pasakyti, kad dalis autorių pabrěžia, kad nematerialus turtas naudojamas pridètinei vertei kurti ir formuoja naują materialųji ar nematerialųji turtą. Nematerialus turtas yra ateities augimo šaltinis, o pagrindiniai atributai yra žinios, kompetencija, patirtis, paskatos. Didžia dalimi nematerialus turtas neatneša greitos ekonominès naudos kaip materialus turtas. Nematerialaus turto poveikis ịmonès rodikliams gali pasireikšti praejjus ilgesniam laikotarpiui ir sujungus tam tikrus nematerialaus turto elementus bei užtikrinant aukštą trinties intensyvumo lygị tarp jų.

2 lentelè. Nematerialaus turto apibrèžimai

\begin{tabular}{|c|l|l|}
\hline Metai & \multicolumn{1}{|c|}{ Autorius } & \multicolumn{1}{c|}{ Apibrėžimai } \\
\hline 1997 & Edvinsson & $\begin{array}{l}\text { Nematerialus turtas - ištekliai, kurie neatsispindi įmonių apskai- } \\
\text { toje, bet sukuria pridètinę vertę verslui }\end{array}$ \\
\hline 1997 & Stewart & $\begin{array}{l}\text { Nematerialus turtas - organizacijos patentų, procesų, darbuotojų } \\
\text { igūdžių, technologijų, informacijos apie vartotojus ir tiekèjus suma }\end{array}$ \\
\hline
\end{tabular}




\begin{tabular}{|c|c|c|}
\hline 1997 & Stewart & $\begin{array}{l}\text { Nematerialus turtas - žinios, informacija, intelektinè nuosavybè } \\
\text { ir patirtis, kas gali būti naudojama kuriant kapitalą }\end{array}$ \\
\hline 1997 & Sveiby & $\begin{array}{l}\text { Nematerialus turtas - individo gebejjimas veikti neapibrèžtomis } \\
\text { situacijomis ir kurti apčiuopiamą ir neapčiuopiamą turtą }\end{array}$ \\
\hline 1998 & $\begin{array}{l}\text { Tarptautinis apskaitos } \\
\text { standartų komitetas }\end{array}$ & $\begin{array}{l}\text { Nematerialus turtas - identifikuojamas ne finansinis turtas, ne- } \\
\text { turintis materialaus pavidalo ir naudojamas paslaugų teikimo ar } \\
\text { prekių gamybos procese }\end{array}$ \\
\hline 1998 & $\begin{array}{l}\text { Ekonominés plètros } \\
\text { ir bendradarbiavimo } \\
\text { organizacija (OECD) }\end{array}$ & Nematerialus turtas - vienas iš verslo investicijų elementų \\
\hline 1999 & Bontis & $\begin{array}{l}\text { Nematerialaus turto komponenčių suma sudaro nematerialųji } \\
\text { kapitalą }\end{array}$ \\
\hline 2000 & Brennan, Connel & $\begin{array}{l}\text { Nematerialus turtas nèra vien tik žmogiškieji resursai, vartotojų } \\
\text { lojalumas ar kompanijos reputacija }\end{array}$ \\
\hline 2000 & Eustace & $\begin{array}{l}\text { Nematerialus turtas - nematerialūs veiksniai, stimuliuojantys } \\
\text { prekių gamybą ar paslaugų teikimą, siekiant ateities naudos sub- } \\
\text { jektams, valdantiems tuos veiksnius }\end{array}$ \\
\hline 2000 & Dzinkowski & Intelektinis kapitalas virsta nematerialiuoju turtu \\
\hline 2001 & Gu, Lev & $\begin{array}{l}\text { Nematerialus turtas - apibrèžiamas kaip moksliniai ir tech- } \\
\text { nologiniai tyrimai, marketingas, informacinès technologijos, } \\
\text { žmogiškųjų išteklių praktika }\end{array}$ \\
\hline 2003 & Zambon & $\begin{array}{l}\text { Nematerialus turtas - ateities augimo ištekliai, neturintys mate- } \\
\text { rialaus pavidalo }\end{array}$ \\
\hline 2003 & Abernethy & $\begin{array}{l}\text { Nematerialus turtas - neturintis materialaus pavidalo išteklius, } \\
\text { atnešantis naudą ateityje }\end{array}$ \\
\hline 2005 & Corrado, Hulten, Sichel & $\begin{array}{l}\text { Nematerialus turtas - verslo investicijos ị neapčiuopiamus } \\
\text { išteklius, kurie naudojami gamybos ar paslaugų teikimo procese } \\
\text { ir sukuria vertę ilguoju laikotarpiu }\end{array}$ \\
\hline 2006 & Boekestein & Nematerialus turtas - vienas iš intelektinio kapitalo elementų \\
\hline 2009 & Teece & $\begin{array}{l}\text { Intelektinis kapitalas yra nematerialus turtas, kurị sudaro žinios, } \\
\text { tgūdžiai, prekès ženklai, reputacija, ryšiai su vartotojais ir } \\
\text { intelektinè nuosavybė }\end{array}$ \\
\hline
\end{tabular}

Šaltinis: sudaryta autorių

Materialaus turto sampratoje vyrauja atskiriamumo požymis. İmonių apskaitoje turtas pripažįstamas turtu, kai turi tokias savybes ir gali būti parduotas, perduotas, licencijuotas, išnuomotas ar mainomas (TAS). Nematerialus turtas dažniausiai susideda iš kelių nematerialių elementų sumos (Teece, 2009). Todèl nematerialųjị turtą netgi gali būti sunku priskirti vienai nematerialaus turto rūšiai. Siekiant palengvinti nematerialaus turto identifikavimą, galima nematerialiajam turtui priskirti nedalumo savybę. Dar daugiau, nematerialaus turto naudojimas nemažina šio turto kiekybinių charakteristikų. Pavyzdžiui, suteikiant licenciją naudotis programine ịranga, kiekvieno naujo programinės ịrangos vieneto naudojimas nereikalauja papildomų išteklių. Visi reikalingi ištekliai sukuriant programinę ịrangą jau yra sunaudoti, o galutinis produktas saugomas intelektinès nuosavybės mechanizmų. Kitaip tariant, nematerialaus turto naudojimas nemažina paties turto kiekio ir dydžio. Vadinasi, nematerialaus turto naudojimas yra efektyvus procesas, tausojantis gamtos išteklius ir stip- 
rinantis tvarios ekonominès raidos teoriją. Iš kitos pusès, nematerialus turtas, bent jau tiesiogiai, neišskiria anglies dvideginio ar kitų žalingų medžiagų i aplinką, todèl gamybos ar paslaugų teikimo procese gali būti suvokiamas kaip darnų augimą užtikrinantis veiksnys.

1 schema. Nematerialaus turto savybès

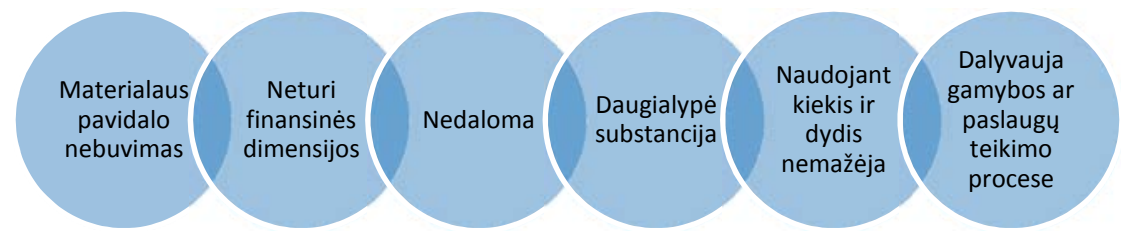

Šaltinis: sudaryta autorių

Teigiama, kad intelektinis kapitalas yra turtas, kuris yra intelektinès veiklos rezultatas, pradedant naujų žinių ịsigijimu iki ryšių užmezgimo (Wiig, 1997). Apibrěžiama, kad intelektinis kapitalas yra specialaus pobūdžio žiniomis pagrịstas turtas, kuris sudaro sąlygas konkurenciniam pranašumui plètoti (Heng, 2001). Keletas autorių sutinka, kad ekonominị turtą kuria žinių turtas, arba kitaip - intelektinis kapitalas (Dean ir Kretchmer, 2007). Kai kurių mokslininkų požiūriu, intelektinis kapitalas yra platesnè sąvoka nei nematerialus turtas, kadangi intelektinis kapitalas papildomai apima skirtingus infrastruktūros aspektus (valdymo filosofiją, informacines sistemas), vartotojų kapitalą (ivvairias licencines sutartis) ir žmogiškajji kapitalą (know-how technologijas, išsilavinimą, profesinę kvalifikaciją, verslininkystès dvasią) (Brennen ir Connell, 2000). Iš kitos pusès, atsižvelgiant ị anksčiau pateiktus nematerialaus turto apibrèžimus, galima teigti, kad valdymo filosofija, informacinès sistemos, profesinè kvalifikacija, gamybos technologijos ir kt. taip pat gali būti traktuojami kaip nematerialus turtas. Remiantis nematerialaus turto samprata ir savybėmis, šie veiksniai dalyvauja gamybos procese ar teikiant paslaugas, neturi materialaus pavidalo, yra naudojami vertei padidinti ateityje, jų naudojimas nemažina jų kiekio bei dydžio.

Nematerialus turtas, intelektiniskapitalas ir žinių kapitalas dažnai suprantami vienodai (Hunter et al., 2012). Nematerialus turtas apibrěžiamas kaip individo gebejjimas generuoti ir kurti pridètinę vertę (Erikson ir Nerdrum, 2001). Zambonas (2003) nematerialų turtą apibrěžia kaip ne fizinị kapitalą, kuris naudą gali suteikti tik ateityje. Nematerialus turtas imlus laikui ir pridètinę vertę gali sukurti tik po tam tikro laiko, priešingai negu materialus kapitalas. Nematerialus kapitalas apibrèžiamas ir kaip prekės ženklų ir kitų žinių vertė, kuri slypi įmonių specifiniuose žmonių ir struktūriniuose ištekliuose (Corrado et al., 2006). Šis procesas glaudžiai susietas su naujų žinių generavimu. Kitais žodžiais tariant, puoselèjant nematerialų turtą, prekès ir paslaugos tampa imlesnès žinioms (Corrado et al., 2009).

Daugelis autorių žmogiškajj kapitalą išskiria kaip nematerialaus turto dedamąją. Anksčiau atlikti tyrimai rodo, kad neoklasikinis ekonomikos augimo modelis, ittraukiantis ir žmogiškajj̣ kapitalą, gali didžia dalimi paaiškinti skirtingo lygio našumą tarp šalių (Mankiw ir Gregory, 1992). Jinnai (2009) teigia, kad nematerialus turtas, pasireiškiantis technologijų atsiradimu, svarbus vidutinių verslo ciklų laikotarpiu. Tuo tarpu Perli ir Sakellaris (1998) tyrinejjo žmogiškojo kapitalo, kaip nematerialaus turto, poveikį ekonomikos svyravimams. Daug dèmesio skirta ir verslo ciklų bei nematerialių išteklių tyrimams (Jone et al., 2005). Kiti auto- 
riai (Comin ir Gertler, 2006) nagrinèjo intelektinių atributų itaką vidutiniams verslo ciklams, intelektinio kapitalo apraiškas galutiniame produkto ar paslaugos vartojime (Hou ir Johri, 2009). Dalis mokslininkų tyrinëjo didèjančias nematerialaus kapitalo proporcijas palyginti su materialiuoju kapitalu (Pyo et al., 2012). Geriau suvokiant nematerialaus turto prigimti ir jo egzistavimo ribas, tikslinga analizuoti nematerialaus turto dedamąsias (3 lent.).

3 lentelè. Nematerialaus turto ir kapitalo elementai pagal skirtingus autorius

\begin{tabular}{|c|c|c|}
\hline Nematerialus turtas & Apibūdinimas & Autoriai \\
\hline Nematerialūs ištekliai & $\begin{array}{l}\text { Licencijos, patentai, prekių ženklai, sutartiniai santy- } \\
\text { kiai su klientais, kuriamas turtas, nebaigti projektai, } \\
\text { programine įranga, žemės nuomos teisès, aplinkos } \\
\text { taršos leidimai, plètros išlaidos individualiems } \\
\text { projektams }\end{array}$ & $\begin{array}{l}\text { Rudytė ir } \\
\text { Bužinskienè } \\
(2012)\end{array}$ \\
\hline Nematerialus turtas & $\begin{array}{l}\text { Plètros darbai, patentai, licencijos, autorių ir gretutinès } \\
\text { teisès, frančizè, programinè ịranga, klientų sąrašai, } \\
\text { nekonkuravimo sutartys, prestižas, sutartys su klientais }\end{array}$ & $\begin{array}{l}\text { Mackevičius ir } \\
\text { Jarmalaitė } \\
(2011)\end{array}$ \\
\hline Nematerialus turtas & $\begin{array}{l}\text { Prekès ir ịmonių ženklai, rinkos dalis, profilaktinès } \\
\text { programos, specifinės žinios ir gebejimai, regioniniai } \\
\text { susitarimai, partnerystė su konkurentais, licencijos, } \\
\text { restruktūrizavimo strategija, mokesčių planavimo } \\
\text { strategija, kokybès sertifikatai, kiti sertifikatai }\end{array}$ & $\begin{array}{l}\text { Lopes ir Rodrigues } \\
(2007)\end{array}$ \\
\hline $\begin{array}{l}\text { Kompiuterizuota } \\
\text { informacija }\end{array}$ & Programinè ịranga, duomenų bazès & \multirow{3}{*}{$\begin{array}{l}\text { Corrada et al., } \\
\text { (2005), } \\
\text { Pekkola (2011), } \\
\text { OECD (2013) }\end{array}$} \\
\hline Inovacinè nuosavybė & $\begin{array}{l}\text { Moksliniai tyrimai ir eksperimentinè plètra, minerali- } \\
\text { nių medžiagų tyrinèjimas, autorinès teisès ir kūrybinis } \\
\text { kapitalas, naujų produktų kūrimas finansiniame } \\
\text { sektoriuje, nauja architektūra ir inžinerinis dizainas }\end{array}$ & \\
\hline $\begin{array}{l}\text { Ekonominès } \\
\text { kompetencijos }\end{array}$ & $\begin{array}{l}\text { Prekès ženklo rinkodara, rinkos tyrimai, išorès konsul- } \\
\text { tavimas plètros klausimais, organizacinè struktūra }\end{array}$ & \\
\hline $\begin{array}{l}\text { Nematerialaus turto } \\
\text { pirkimas }\end{array}$ & $\begin{array}{l}\text { İsigyjamas turtas kaip patentai, įmonių ir prekių } \\
\text { ženklai, prestižas įsigytas verslo jungimo metu }\end{array}$ & \multirow[t]{4}{*}{ Abernethy (2003) } \\
\hline Tyrimai ir plètra & $\begin{array}{l}\text { Išlaidos, susijusios su moksliniais ir taikomaisiais } \\
\text { tyrimais ir skirtos įmonės plètrai }\end{array}$ & \\
\hline $\begin{array}{l}\text { Imonès viduje } \\
\text { sukurtas nematerialus } \\
\text { turtas }\end{array}$ & $\begin{array}{l}\text { Tai apima įmonès informacinę sistemą, administ- } \\
\text { ravimo struktūrą ir procesus, rinkas ir technologines } \\
\text { žinias, prekybines paslaptis, pirkejų ir tiekejų tinklus }\end{array}$ & \\
\hline Intelektinè nuosavybè & $\begin{array}{l}\text { Tai apima teisines normas arba sutartines teises: } \\
\text { patentai, Ł̇monių ženklai, projektavimas, licencijos, } \\
\text { autorinès teisès, Ł̇monių teisés ir kt. }\end{array}$ & \\
\hline Žmogiškasis kapitalas & $\begin{array}{l}\text { Individo ekspertinės žinios, igūdžiai, patirtis, } \\
\text { išsilavinimas, inovatyvumas, darbuotojų } \\
\text { kompetencija, motyvacija, lojalumas }\end{array}$ & $\begin{array}{l}\text { Stewart (1997), } \\
\text { Bontis (1998) }\end{array}$ \\
\hline
\end{tabular}




\begin{tabular}{|c|c|c|}
\hline Ryšių kapitalas & $\begin{array}{l}\text { Imonès frančizès vertè, santykių su klientais (indivi- } \\
\text { dais ir organizacijomis) tęstinumas, klientų išlaikymas, } \\
\text { klientų pelningumas }\end{array}$ & \\
\hline Struktūrinis kapitalas & $\begin{array}{l}\text { Gamybinès technologijos, išradimai, duomenys, } \\
\text { publikacijos, strategija, kultūra, organizacijos rutina ir } \\
\text { procedūros, organizacinè struktūra, patentai, prekių } \\
\text { ženklai, programinè îranga, santykiai su tiekejjais, } \\
\text { rinkos ir konkurencingumo ǐžvalgos }\end{array}$ & \\
\hline Inovacijų kapitalas & Moksliniai ir technologiniai tyrimai & \multirow{5}{*}{$\begin{array}{l}\text { Mortensen et al., } \\
\text { (1997) }\end{array}$} \\
\hline Struktūrinis kapitalas & $\begin{array}{l}\text { Žinių turtas, organizacinè sanglauda, lankstumas, } \\
\text { darbuotojų igūdžiai ir lojalumas }\end{array}$ & \\
\hline Vykdomosios sutartys & $\begin{array}{l}\text { Licencijos, frančizès, kvotos reguliuojamuose } \\
\text { sektoriuose, paslaugų užsakymas iš išorès vidaus } \\
\text { veiklos poreikiams tenkinti per metus, finansinès } \\
\text { rizikas mažinančios priemonès }\end{array}$ & \\
\hline Rinkos kapitalas & Prekių ir įmonių ženklai & \\
\hline Prestižas & Reputacija & \\
\hline $\begin{array}{l}\text { Darbuotojų } \\
\text { kompetencija }\end{array}$ & $\begin{array}{l}\text { Gebejjimas elgtis neapibrèžtose situacijose, igūdžiai, } \\
\text { išsilavinimas, patirtis, vertybės ir motyvacija }\end{array}$ & \multirow[t]{3}{*}{ Sveiby (1997) } \\
\hline Vidaus struktūra & $\begin{array}{l}\text { Patentai, koncepcijos, modeliai, administravimo } \\
\text { sistemos, organizacijos kultūra }\end{array}$ & \\
\hline Išorès struktūra & $\begin{array}{l}\text { Santykiai su klientais, tiekèjais, prekių ir ịmonės } \\
\text { ženklai, organizacijos ịvaizdis. }\end{array}$ & \\
\hline Rinkos turtas & $\begin{array}{l}\text { Igyta rinkos dalis dèl su rinka susijusiu nematerialiu } \\
\text { turtu: prekių ženklais, vartotojais, distribucijos } \\
\text { kanalais, susitarimais }\end{array}$ & \multirow[t]{3}{*}{ Brooking (1996) } \\
\hline $\begin{array}{l}\text { Žmogaus orientuotas } \\
\text { turtas }\end{array}$ & $\begin{array}{l}\text { Kolektyvinès ekspertinės žinios, lyderystė, verslumo ir } \\
\text { vadybiniai igūdžiai }\end{array}$ & \\
\hline Intelektinis turtas & $\begin{array}{l}\text { Know-how technologija, komercinės paslaptys, } \\
\text { patentai, įmonių ženklai }\end{array}$ & \\
\hline $\begin{array}{l}\text { Tradicinis } \\
\text { nematerialus turtas }\end{array}$ & Reputacija, prekės ženklas, patentai & \multirow[t]{2}{*}{$\begin{array}{l}\text { Hendriksen ir } \\
\text { Van Breda (1992) }\end{array}$} \\
\hline $\begin{array}{l}\text { Sąnaudos patirtos } \\
\text { einamuoju laikotarpiu, } \\
\text { bet naudą atneš ateityje }\end{array}$ & Reklama, moksliniai tyrimai, mokymai & \\
\hline Nematerialus turtas & $\begin{array}{l}\text { Imonių ženklai, patentai, dizainas, komercinès paslap- } \\
\text { tys, reputacija, tinklai, prekès ženklai }\end{array}$ & Hall (1992) \\
\hline
\end{tabular}

Šaltinis: sudaryta autorių

Nematerialaus turto ekonominès minties formavimosi pradžioje suformuota nuomonè, kad nematerialus turtas apima tik žmogiškuosius išteklius ir mokslinius tyrimus, yra ganėtinai ribota. Tačiau dabar jau tampa aišku, kad nematerialus turtas yra žymiai platesnè 
naujosios ekonomikos formavimosi dimensija. Mokslo pasaulyje plačiausiai paplito trijų JAV mokslininkų Corrado, Sichelo ir Hulteno suformuota nematerialaus turto koncepcija, empiriškai pritaikyta Jungtinèse Valstijose, vèliau OECD šalyse, o $2011 \mathrm{~m}$. ir Europos Sąungos šalyse. Nematerialaus turto koncepcijos autoriai nematerialujji turtą suklasifikavo i tris pagrindines sritis: kompiuterizuota informacija, inovacinè nuosavybè ir ekonominès kompetencijos. Patys amerikiečiu mokslininkai pripažizsta, kad jų pateikta nematerialaus turto koncepcija turi potencialo būti išplėsta. Tačiau jau suformuota ir taikoma koncepcija yra puikus ịrankis pažinti nematerialaus turto tyrimų sriți ir yra pirmas reikšmingas indèlis šioje tyrimų srityje.

\section{Išvados}

Nematerialaus turto konceptualiosios žinios dar nesuformavo savo sanklodos ekonomikos moksle. Nematerialaus turto ekonominès minties istorijos analizè siūlo daryti išvadą, kad darbo jèga, o veliau žmogiškasis kapitalas, moksliniai tyrimai ir technologiné pažanga nuolat, bet netiesiogiai stimuliavo nematerialaus turto formavimąsi.

Atliktas tyrimas parode, kad nematerialaus turto samprata yra plati ir traktuojama įvairiai. Autoriai atkreipia dėmesị $\mathfrak{i}$ vieną ar kitą nematerialaus turto aspektą, priklausomai nuo tyrimo konteksto, keliamų tikslų ir uždavinių.

Apibendrinę nematerialaus turto formavimuisi ịtakos turejusias ekonomines koncepcijas, dabar vyraujančią ekonominès minties teoriją ir nematerialaus turto savybes bei elementus, autoriai galëjo suformuoti ir pateikti universalų nematerialaus turto apibrežimą: nematerialus turtas - tai materija, pasižyminti materialaus pavidalo nebuvimu, nedalumu, neturinti finansinès dimensijos, o šios materijos, kurios formavimąsi stimuliuoja žmogiškasis kapitalas, mokslo ir technologine pažanga, naudojimas gamybos ar paslaugų teikimo procese nekeičia jos dydžio, formos ar priskiriamų ekonominių charakteristikų, turinčių tikslinę orientaciją didinti bendrą produktyvumo lygị ir vertę kurti ilguoju laikotarpiu.

Nepaisant atliktų tyrimų ir nematerialaus turto sampratos analizės, nematerialus turtas ir jo poveikis ekonomikai nèra galutinai ištirtas. Straipsnio autorių manymu, nematerialaus turto koncepcinių žinių ir vertinimo metodologijos formavimas gali būti traktuojami kaip viena perspektyviausių tyrimų sričiu Lietuvoje ir užsienyje.

\section{Literatūros sąrašas}

Abernethy, M. A., and Wyatt, A. (2003). Framework for measurement and reporting on intangible assets. Intellectual Property Research Institute of Australia.

Abramovitz, M., and David, P. A. (1996). Economic growth in the US, in Employment and Growth in the knowledge-based economy, OECD.

Becker, G. S. (1962). Investment in human capital: a theoretical analysis. New York. Columbia University Press for the National Bureau of Economic Analysis.

Boekestein, B. (2006). The relation between intellectual capital and intangible assets of pharmaceutical companies. Journal of Intellectual Capital, 7(2): 241-253.

Bontis, N. (1998). Intellectual capital: an exploratory study that develops measures and models. Management Decision, 36 (2): 63-76.

Bontis, N. (1999). Managing organizational knowledge by diagnosing intellectual capital: framing and advancing the state of the field. International Journal of Technology Management, Vol. 18, No. 8: 433-462. 
Brenann, N., and Connell, B. (2000). Intellectual capital: current issues and policy implications. 23rd Annual Congress of Eauropean Accounting Association, Munich, Germany.

Brooking, A. (1996). Intellectual capital: core assets for the third millennium enterprise. London: Thomson Business Press.

Comin, D., and Gertler, M. (2006). Medium term business cycles. American Economic Review, 96(3): 523-551.

Corrado, C., Haskel, Jona-Lasinio, C., and Iommi, M. (2012). Intangible capital and growth in advanced economies: measurement methods and comparative results. Working paper, INTAN-INVEST project.

Corrado, C., Hao, J. X., Hulten, C., and van Ark, B. (2009). Measuring intangible capital and its contribution to economic growth in Europe. European Investment Bank Papers, 14(1), 63-93.

Corrado, C., Hulten, C., and Sichel, D. (2006). Intangible capital and economic growth, Working Paper 11948.

Corrado, C. A., Hulten, C. R., and Sichel, D. (2005). Measuring capital and technology: an expanded framework. National Bureau of Economic Research and University of Chicago Press.

Dal Borgo, M., Goodridge, P., Haskel, J., and Pesole, A. (2012). Productivity and growth in UK industries: an intangible investment approach. Oxford of Bulletin of Economics and Statistics.

Dean, A., and Kretchmer, M. (2007). Can ideas be capital? Factors of production in the postindustrial economy: a review and critique. Academy of Management Review, Vol. 32, No. 2: 573-594.

Denison, E. F. (1967). Why growth rates differ: postwar experience in nine western countries, Brookings institution.

Denison, E. F. (1962). The source of economic growth in the United States and the alternatives before us. Committee for Economic Development.

Denison, E. F. (1979). Accounting for slower economic growth: the United States in the 1970s. Brooking institution.

Dzinkowski, R. (2000). The measurement and management of intellectual capital. Financial Management, Nr. 78.

Edvinsson, L. (1997). Intellectual capital. New York: Harper Business.

Edvinsson, L., and Malone, M. (1997). Intellectual capital: realizing your company's true value by finding its hidden brainpower, HarrperCollins, New York.

Edvinsson, L., and Sullivan, P. (1998). Developing a model for managing intellectual capital. European Management Journal, Vol 14, No. 4: 356-364.

Erikson, T., and Nerdrum, L. (2001). Intellectual capital: a human capital perspective. Journal of Intellectual Capital, 2: 127-135.

Eustace, C. (2001). The intangible economy: impact and policy issues. Report of High Level Expert Group on the Intangible Economy, EU Commission, Brussels.

Goode, R. B. (1959). Adding to the stock of physical and human capital. American Economic Review, 49(2): 147-155.

Granstand, A. (1999). Multi-technology corporations: why they have ,distributed' rather than ,distinctive core' competencies. Technology, management and systems of innovation, 87-104.

Griliches, Z. (1967). Production functions in manufacturing: Some preliminary results. The Theory and Empirical Analysis of Production, NBER, Studies in Income and Wealth, Vol. 31: 275-340.

Griliches, Z. (1984). Research and development, Patents and Productivity. Chicago University Press.

Gu, F., and Lev, B. (2002). Intangible assets: measurement, drivers, usefulness. Working Paper. Stern School of Business, New York University.

Hall, R. (1992). The strategic analysis of intangible resources. Strategic Management Journal, 13(2): 135-144.

Hartwick, J. (1977). Intergenerational equity and investing rents from exhaustible resources. American Economic Review, 67: 972-974.

Hendriksen, E. S., and van Breda, M. F. (1992). Accounting theory. Boston: Irwin.

Heng, M. (2001). Mapping intellectual capital in a small manufacturing enterprise. Journal of Intellectual Capital, Vol. 2, No. 1: 53-60. 
Hou, K., and Johri, A. (2009). Intangible capital, corporate earnings and the business cycle. McMaster University Departament of Economics Working Paper No. 2009-17.

Hunter, L. Webster, E., and Wyatt, A. (2012). Accounting for expenditure in intangibles. ABACUS, 48(1): 104-145.

Jinnai, R. (2009). Intangible capital, asset prices and business cycles. Unpublished paper, Departament of Economic, Princeton University.

Jone, L., Manuelli, R. E., and Siu H. E. (2005). Fluctuations in convex models of endogenous growth II: business cycle properties. Review of Economic Dynamics, 8(4): 805-828.

Jorgenson, D. (1963). Capital theory and investment behaviour. The American Economic Review, 53(2): 247-259, Papers and Proceedings fo the Seventy-fifth Annual Meeting of the American Economic Association.

Kendrick, J. (1961). Productivity trends in the United States, Princeton Press.

Kendrick, J. (1994). Total capital and economic growth. Atlantic Economic Journal, Vol. 22.

Lev, B., and Gu, L. (2001). Intangibles. Management, measurement and reporting. Brookings institution Press, Washington, D. C.

Lopes I. T., and Rodrigues, A. M. G. (2007). Intangible assets identification and valuation - a theoretical framework approach to the Portuguese airlines companies. Electronic Journal of Knowledge Management. 5(2): 193-202.

Mackevičius, J., ir Jarmalaitė, J. (2011). Nematerialieji ištekliai kaip apskaitos objektas: samprata, pripažinimas ir klasifikavimas. Current Issues of Business and Law, 6(2): 302-318.

Mankiw, N., and Gregory, D. (1992). A contribution to the empirics of economic growth. Quarterly Journal of Economics, 107: 407-437.

Marrano, M. G., and Haskel, J. (2006). How much does the UK invest in intangible assets? Queen Mary, University of London, Working Paper No. 578.

Marrocu, E., Paci, R., and Pontis, M. (2012). Intangible capital and firms productivity. Industrial Corporate Change, 21(2): 377-402.

Marx, K. (1867). Capital. A critique of political economy. Volume I. Book one: the process of production of capital. Germany.

Melachroinos, K. A., and Spence, N. (2012). Intangible investment and regional productivity in Great Britain, Regional Studies.

Mincer, J. (1958). Investment in human capital and personal income distribution. Journal of Political Economy, 66(4): 281-302.

Mortensen, J., Eustace, C., and Lannoo, K. (1997). Intangibles in the European economy. Paper preseted at the CEPS workshop on intangibles in the European economy. Brussels.

OECD (1998). National efforts to measure intangible investment. OECD, Paris.

OECD (2001). The New Economy: Beyond the Hype, OECD, Paris

OECD. (2013). Supporting investment in knowledge capital, growth and innovation. OECD Publishing.

Perli, R., and Sakellaris, P. (1998). Human capital formation and business cycle persistance. Journal of Monetary Economics, 42(1): 67-92.

Pezzey, J. (1992) Sustainable Development Concepts. An Economic Analysis / World Bank Environment Paper, No. 2.

Piekkola, H. (2011). Intangible capital - driver of growth in Europe. Proceedings of the university of Vaasa.

Piekkola, H. ed. (2011). Intangible capital - driver of growth in Europe. Proceedings of the University of Vaasa.

Pyo, K., Chun, H., and Rhee, K. (2012). Intangible capital and economic growth: a theoretical model and further evidence. The second World KLEMS conference, Harvard University.

Repetto R. (1986). World Enough and Time. New Haven, CT: Yale University Press.

Riley, R., Gorzing, B., and Piekkola, H. (2011). Production of intangible investment and growth: methodology in INNODRIVE.

Romer, P. M. (1994). The origins of endogenous growth. Journal of Economic Perspectives, Vol. 8, No. 1: $3-22$. 
Roth, F., and Thum, A-E. (2013). Intangible capital and labor productivity growth: panel evidence for the EU from 1998-2005. Review of Income and Wealth, Vol 2, No. 2: 26-38.

Rudytè, D., ir Bužinskienė, R. (2012). Skirtingų valstybių nematerialaus turto struktūros analizè ir vertinimas Lietuvoje. Ekonomika ir vadyba: aktualijos ir perspektyvos, (28): 133-141.

Schumpeter, J. A. (1942). Capitalism, socialism and democracy. First edition in UK 1943.

Smith, A. (1776). An Inquiry into the nature and causes of the wealth of nations.

Solow, R. M. (1974). Intergenerational equity and exhaustible resources. The Review of Economic Studies, Vol. 41: 29-45.

Solow, R. M. (1956). A contribution to the theory of economic growth. Quarterly Journal of Economics, 70(1): 65-94.

Stewart, T. A. (1997). Intellectual capital - the new wealth of organizations. 1st edition, London: Nicolas Brealey Publishing.

Sveiby, K. E. (1997). The new organizational wealth: managing and measuring knowledge-based assets. San Francisco: Berret-Koehler.

Swan, T. W. (1956). Economic growth and capital accumulation. Economic Record, 32(63): 334-361.

Teece, J. D. (2009). Managing intellectual capital. Organizational, strategic and policy dimensions. New York: Oxford University Press.

Wiig, K. M. (1997). Knowledge management. An introduction and perspective. Journal of Knowledge Management. Vol. 1, No. 1:6-8.

Zambon, S. (2003). Study on the measurement of intangible assets and associated reporting practices. Commission of the European Communities, Enterprise Directorate General, Brussels.

\title{
INTANGIBLE ASSET CONCEPT: ECONOMIC THOUGHT DEVELOPMENT, DEFINITIONS, PECULIARITIES AND ELEMENTS
}

\author{
Raimundas DUŽINSKAS \\ Artūras JURGELEVIČIUS \\ Mykolas Romeris University, Lithuania
}

Summary. Classical economic theories can explain modern economic processes only to some extent. Economic growth theories were explained by many distinguished economists, such as Marx, Smith, Riccardo, Schumpeter, Becker and many others. The classical means of production were the main object in the interest of the economists researching and explaining economic growth. However, more sophisticated economy demands new methods and methodology to explain the same processes: growth, productivity, effectiveness, competitiveness. Unexplained growth in productivity in the second part of the 20th century was the beginning of new scientific research of intangible assets. However, at the time rapid growth in productivity was explained mainly by better human resources and technological progress. Intangible assets were not taken into account and were ignored by many economists and accountants for a long period of time because of the problems of identification, valuation and measurement of intangible assets. Various scientists of the field interpreted intangible assets according to their understanding. However, the growing number of literature on intangible assets suggests that this issue is becoming interesting enough and significant for the companies and economy in general. The aim of the paper is, after having analyzed economic thought development and discussing problematic issues of identification of intangible assets, to analyze elements of intangible assets and formulate universal definition of intangible assets. The object of the paper is intangible assets. The methods used are systematic classification and analysis of scientific literature in the field of intangible assets.

Keywords: intangible assets, historical development of intangible assets economic thought, intangible assets concept, intangible assets elements. 